\title{
Spatial variability of soil fertility and its relationship with seed physiological potential in a soybean production area $^{1}$
}

\author{
Vitor Henrique Vaz Mondo ${ }^{2 *}$, Francisco Guilhien Gomes Junior ${ }^{2}$, Taís Leite \\ Ferreira Pinto², José Luis de Marchi², Anamari Viegas de Araújo Motomiya ${ }^{3}$, \\ José Paulo Molin ${ }^{4}$, Silvio Moure Cicero²
}

\begin{abstract}
The correlation of soil fertility $\mathrm{x}$ seed physiological potential is very important in the area of seed technology but results published with that theme are contradictory. For this reason, this study to evaluate the correlations between soil chemical properties and physiological potential of soybean seeds. On georeferenced points, both soil and seeds were sampled for analysis of soil fertility and seed physiological potential. Data were assessed by the following analyses: descriptive statistics; Pearson's linear correlation; and geostatistics. The adjusted parameters of the semivariograms were used to produce maps of spatial distribution for each variable. Organic matter content, $\mathrm{Mn}$ and $\mathrm{Cu}$ showed significant effects on seed germination. Most variables studied presented moderate to high spatial dependence. Germination and accelerated aging of seeds, and $\mathrm{P}$, $\mathrm{Ca}, \mathrm{Mg}, \mathrm{Mn}, \mathrm{Cu}$ and $\mathrm{Zn}$ showed a better fit to spherical semivariogram: organic matter, $\mathrm{pH}$ and $\mathrm{K}$ had a better fit to Gaussian model; and V\% and Fe showed a better fit to the linear model. The values for range of spatial dependence varied from $89.9 \mathrm{~m}$ for P until $651.4 \mathrm{~m}$ for Fe. These values should be considered when new samples are collected for assessing soil fertility in this production area.
\end{abstract}

Index terms: Glycine max, precision agriculture, seed quality.

\section{Variabilidade espacial da fertilidade do solo e sua relação com o potencial fisiológico de sementes em área de produção de soja}

\begin{abstract}
RESUMO - A correlação fertilidade do solo x potencial fisiológico da semente é importante na área de tecnologia de sementes, porém os resultados publicados são contraditórios. Assim, este trabalho objetivou avaliar as correlações entre atributos químicos do solo e potencial fisiológico de sementes de soja. Foram realizadas amostragens de solo e sementes, em pontos georreferenciados, para análise da fertilidade do solo e potencial fisiológico de sementes. Os dados foram submetidos às análises de estatística descritiva, correlação linear de Pearson e geoestatística. Os parâmetros dos semivariogramas ajustados foram utilizados para elaboração de mapas de distribuição espacial das variáveis. Teores de matéria orgânica, $\mathrm{Mn}$ e $\mathrm{Cu}$ apresentaram efeitos significativos sobre a germinação das sementes. A maioria das variáveis estudadas apresentou dependência espacial de moderada a elevada. Germinação e envelhecimento acelerado das sementes e $\mathrm{P}, \mathrm{Ca}, \mathrm{Mg}, \mathrm{Mn}, \mathrm{Cu}$ e $\mathrm{Zn}$ no solo apresentaram ajuste ao semivariograma esférico; matéria orgânica, $\mathrm{pH}$ e $\mathrm{K}$ apresentaram ajuste ao modelo gaussiano; e V\% e Fe apresentaram ajuste ao modelo linear. Os valores do alcance de dependência espacial variaram de $89,9 \mathrm{~m}$ para $\mathrm{P}$ até $651,4 \mathrm{~m}$ para Fe. Estes valores devem ser considerados quando novas amostragens forem realizadas para avaliação da fertilidade do solo nesta área de produção.
\end{abstract}

Termos para indexação: Glycine max, agricultura de precisão, qualidade de sementes.

${ }^{1}$ Submitted on 11/20/2010. Accepted for publication on 11/28/2011.

${ }^{2}$ Departamento de Produção Vegetal, Universidade de São Paulo, Caixa Postal 9, 13418-900 - Piracicaba, SP, Brasil.

${ }^{3}$ Universidade Federal da Grande Dourados, Faculdade de Ciências Agrárias, 79825-070 - Dourados, MS, Brasil.
${ }^{4}$ Departamento de Engenharia Rural, Universidade de São de Paulo, Caixa Postal 9, 13418-900 - Piracicaba, SP, Brasil.

*Corresponding author < vhvmondo@yahoo.com.br> 


\section{Introduction}

Precision Agriculture is a system of management or of managing the agricultural production composed of technologies and procedures used for the improvement of crop fields and production systems. It aims to use efficient production resources, minimization of undesirable effects to environment and to increase productivity, having as key element the managing of the spatial variability of production and of related factors.

The variability of productivity on a given crop can be inherent to soil or to climate or yet induced by the crop management interacting with the plant genotype. Among the changes in the physical, chemical and biological properties of soil, caused by management practices are: the soil compaction by agricultural machinery traffic; the variability of the stand of plants in the field; and the content of nutrients in the soil, due to non-uniform distribution of seeds, fertilizers or correctives (Runge and Hons, 1998; Plant et al., 1999).

Various studies have been carried out aiming at establishing correlations between crop productivity and physicochemical properties or soil relief characteristics as well as other variables, thus establishing the main influence factors (Khakural et al., 1999; Kravchenko and Bullock, 2000). In addition, there are other factors that cause variability and that deserve further studies based on the possibility of sorting the products into different quality classes and that bring economical advantages for the demanding markets in relation to quality of products (McBratney et al., 2006). The quality criterion is particularly important for high economical value crops. Research works on this matter have been carried out by Tisseyre et al. (2001) and Ortega et al. (2003) with the crop of grape (Vitis vinifera L.) and Stoorvogel et al. $(2000,2004)$ with the crops of Kiwi [Actinidia deliciosa (A. Chev.) E. F. Liang et A.R. Ferguson] and banana (Musa spp.). The mapping of quality characteristics can aid the improvement of the agronomical management of crops (McBratney et al., 2006).

Within this context, the area of seed production involves both the need of an optimized and highly productive system and a high quality product. To reach these objectives, the naturally fertile soils are preferred. The availability of areas with such characteristics, however, not always occurs, which results in the need of utilizing soils varying from median to low fertility (Carvalho and Nakagawa, 2000).
According to Delouche (1980), to obtain high quality seeds, an adequate mineral fertilization is indispensable. A well nourished plant presents better condition to produce seeds with both good quantity and quality, thus providing nutrient for the formation of the embryonic axis and storage organs, consequently influencing the seed capacity of generating a normal seedling. However, just a few studies have been conducted correlating fertilization and nutrition of plants with the seed physiological potential and, besides that, the scarce results reported are not always unanimous (Carvalho and Nakagawa, 2000). Crusciol et al. (2003) observed soon after harvest that the application of different dosages of $\mathrm{N}$ did not induce consistent results on the seed physiological quality, and reported that there was no effect of nitrogen fertilization on the germination and vigor of common beans (Phaseolus vulgaris L.) seeds. Oppositely, Farinelli et al. (2006) observed that fertilization with nitrogen on common beans presented an increasing function, providing a linear increase on seed germination when the dosages of $\mathrm{N}$ were increased.

Therefore, the spatial variability of soil fertility in seed production areas and its possible correlation with the quality of these seeds deserve special attention. Within this research work, the correlations between soil chemical attributes and soybean seeds physiological potential were assessed by means of spatiality techniques as well as of the spatial variability of such attributes by means of geostatistical techniques

\section{Material and Methods}

Data were collected within a 22.2 hectares area, located in "Lagoa Velha" farm, in the city of "Campos Novos

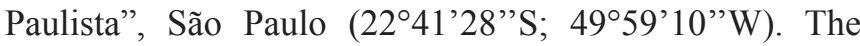
soybean cultivar BRS 245 was used; and the sowing was performed in November 22 $2^{\text {nd }}, 2006$. For seed sampling, the harvest was manually performed in March $10^{\text {th }}, 2007$. Based on a predefined grid, with 63 georeferenced points (Figure 1) 40 plants were randomly collected at each point, within a $5 \mathrm{~m}$ radius from the georeferenced original point, for composing the seed samples. Pods were manually threshed and seeds were assessed for physiological quality.

Soil sampling was manually performed at the end of the crop cycle with the aid of a Dutch Auger, and was carried out simultaneously with seed sampling. Soil samples were collected in 33 sites within the area previously described (Figure 1) in the predefined 
georeferenced points coinciding with the sites used for seed sampling. At each site, 10 simple samples were collected at the depth varying from 0 to $20 \mathrm{~cm}$, within a $5 \mathrm{~m}$ radius from the georeferenced point. These simple samples were then mixed together to obtain the pooled sample for chemical analysis in the laboratory. The initial characterization of seeds was performed by means of determining the moisture content using the oven method at $105 \pm 3{ }^{\circ} \mathrm{C}$, for $24 \mathrm{~h}$, and of the mass of 1,000 seeds, according to methodology described in the Rules for Seed Analysis (Brasil, 2009). Data on mass of 1,000 seeds were corrected to $13 \%$ moisture content.

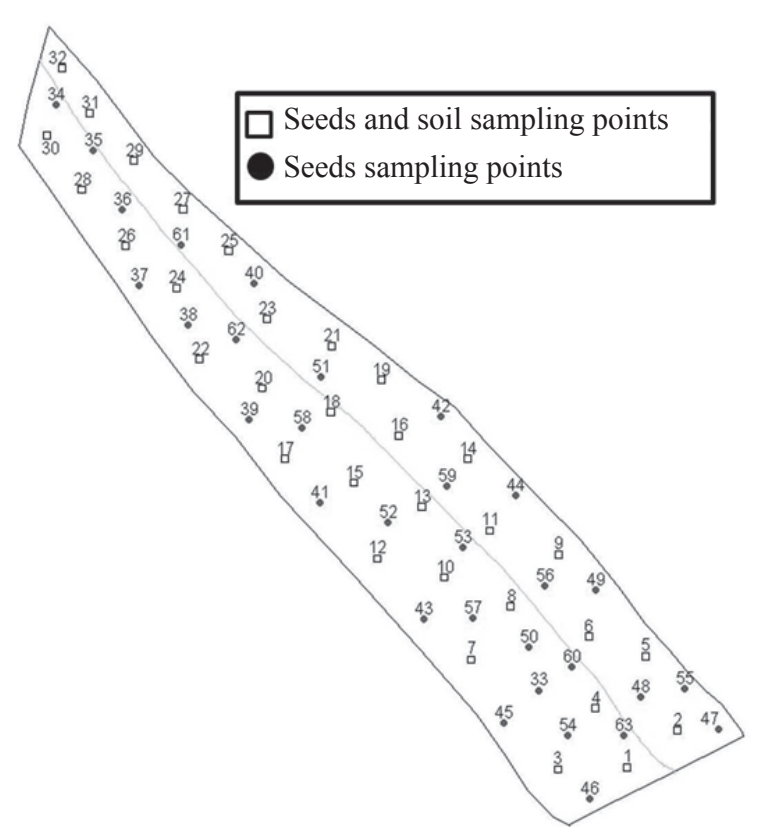

Figure 1. Sampling grid with predefined and georeferenced points.

To assess differences on physiological potential of seeds the tests of germination and accelerated aging were carried out. The germination test was performed with four replications of 50 seeds each, for each seed sample. To accomplish this test, the seeds were sown on top of two sheets of "Germitest" paper towels previously moistened with $\mathrm{H}_{2} \mathrm{O}$, in a volume equivalent to 2.5 times the dry mass of the substrate and covered with another sheet of the same paper towel. The set was then turned into rolls, which were kept into a seed germinator previously set at $25^{\circ} \mathrm{C}$, in the dark. The assessment of normal seedlings was performed at the fourth and seventh day, thus obtaining results for the tests of vigor and first count of germination, according to Rules for Seed Analysis (Brasil, 2009) and the results for germination were expressed in percentage.

The accelerated aging test was carried out using four replications of 50 seeds each, for each replication. The seeds of each replication were placed to germinate into transparent plastic germination boxes (11 cm x $11 \mathrm{~cm}$ x $3 \mathrm{~cm})$, arranged on a single layer on top of a stainless screen fixed on the upper part of a gerbox containing $40 \mathrm{~mL}$ of sterile distilled $\mathrm{H} 2 \mathrm{O}$ and maintained into an aging chamber set at $42{ }^{\circ} \mathrm{C}$ and $100 \%$ relative humidity (Marcos-Filho, 1999). The assessment of normal seedling was performed, as prescribed by the Rules for Seed Analysis (Brasil, 2009), at four days after starting the germination test. Based on results of this test the seed lots were sorted onto: high vigor lots, when figures were equal or higher than $80 \%$ of normal seedlings; and low vigor lots, when results were below that value.

Grain yield data were obtained with a $\mathrm{CNH}$ combine harvester, Model T C59, equipped with a PLMS New Holland (AgLeader) productivity monitor, connected to a GPS Trimble Ag 132 receptor. The monitor also has a seed moisture content sensor and the results were corrected to $13 \%$ moisture content.

The data were subjected to descriptive statistical analysis, Pearson's linear correlation analysis, and geostatistics analysis using the Progeostat program (Vieira et al., 2002). The geostatistics analysis was performed through adjustment of data to the experimental semivariogram, according to the theory of organized variables (TOV). The models selected were subjected to the "M k-knife" technique, according to recommendation of Vieira (2000). The Degree of Spatial Dependence (DSD) was verified by the correlation between the structural variance $(C)$ and the plateau $\left(\mathrm{C}_{0}+\mathrm{C}\right)$ being sorted as: weak dependence, for values $\leq 25 \%$; moderate dependence, for values between $25 \%$ and $75 \%$; and strong dependence, for values $\geq 75 \%$.

Once the spatial dependence was verified, the kriging was performed to estimate values of non-sampled sites, without trends and minimal variance. From the kriging, maps for the spatial distribution of the variables studied were generated.

\section{Results and Discussion}

As compared to limits established for soil fertility levels for soybean crop in the State of São Paulo (Raij et al., 1996), the mean values of chemical attributes were low for $\mathrm{K}$ and $\mathrm{MO}$ and moderate for $\mathrm{pH}$ and $\mathrm{V} \%$ (Table 1). The mean contents of micronutrients were moderate for $\mathrm{B}$, 
$\mathrm{Fe}, \mathrm{Mn}$, and adequate for $\mathrm{Cu}$ and $\mathrm{Zn}$. In general, although the mean for the values of attributes have remained within the range of average fertility, the values had large amplitudes within the area studied, with spots with low fertility levels. For Corá et al. (2004) large amplitude of values indicates problems that can occur when average values of attributes are used as base for decision taking on carrying out a chemical management of the soil, i.e., in some spots, the recommended dosage of fertilizers or correctives will be underestimated; in other spots it will be adequate; and yet in others, an excessive application of a given fertilizer or corrective could occur. Such situation results in economical losses either due to the unnecessary application or in consequence of the imbalance among quantities of nutrients that will be available for plants

Table 1. Values for interval of variation of mean (M), variance (V), and standard deviation (SD); and coefficient of variation $(\mathrm{CV})$ of soil attributes and soybean seeds.

\begin{tabular}{|c|c|c|c|c|c|c|c|c|}
\hline & M & V & SD & $\mathrm{CV}(\%)$ & Minimum & Maximum & Asymmetry & Kurtosis \\
\hline & \multicolumn{8}{|c|}{ Soil attributes } \\
\hline P resin $\left(1 \mathrm{M} \cdot \mathrm{dm}^{-3}\right)$ & 33.55 & 69.69 & 8.35 & 24.89 & 17.00 & 53.00 & 0.51 & 0.20 \\
\hline Organic matter $\left(\mathrm{g} \cdot \mathrm{dm}^{-3}\right)$ & 16.39 & 20.00 & 4.47 & 27.28 & 9.00 & 27.00 & 0.44 & -0.47 \\
\hline $\mathrm{pH} \mathrm{CaCl}{ }_{2}$ & 4.95 & 0.04 & 0.21 & 4.17 & 4.50 & 5.40 & -0.07 & -0.24 \\
\hline $\mathrm{K}^{+}\left(\mathrm{Mmol} \cdot \mathrm{dm}^{-3}\right)$ & 1.33 & 0.07 & 0.27 & 19.93 & 1.00 & 2.50 & 2.83 & 11.68 \\
\hline $\mathrm{Ca}^{++}\left(\mathrm{Mmol}_{\mathrm{dm}}{ }^{-3}\right)$ & 23.88 & 10.36 & 3.22 & 13.48 & 17.00 & 32.00 & 0.32 & 0.08 \\
\hline $\mathrm{Mg}^{++}\left(\mathrm{Mmol} \cdot \mathrm{dm}^{-3}\right)$ & 6.33 & 1.42 & 1.19 & 18.79 & 4.00 & 9.00 & 0.25 & -0.56 \\
\hline V (\%) & 57.82 & 25.65 & 5.07 & 8.76 & 47.00 & 68.00 & -0.40 & -0.13 \\
\hline $\mathrm{B}\left(1 \mathrm{M} \cdot \mathrm{dm}^{-3}\right)$ & 0.58 & 0.03 & 0.18 & 30.67 & 0.38 & 1.11 & 1.18 & 0.99 \\
\hline $\mathrm{Fe}\left(1 \mathrm{M} \cdot \mathrm{dm}^{-3}\right)$ & 21.79 & 19.05 & 4.37 & 20.03 & 13.80 & 29.60 & -0.01 & -1.01 \\
\hline $\operatorname{Mn}\left(1 \mathrm{M} / \mathrm{dm}^{3}\right)$ & 7.54 & 38.61 & 6.21 & 82.42 & 2.30 & 26.40 & 1.87 & 2.76 \\
\hline $\mathrm{Cu}\left(1 \mathrm{M} \cdot \mathrm{dm}^{-3}\right)$ & 0.72 & 0.01 & 0.12 & 16.20 & 0.50 & 1.00 & 0.36 & -0.41 \\
\hline \multirow[t]{2}{*}{$\mathrm{Zn}\left(1 \mathrm{M} \cdot \mathrm{dm}^{-3}\right)$} & 1.77 & 0.29 & 0.54 & 30.47 & 0.70 & 3.00 & 0.06 & -0.05 \\
\hline & \multicolumn{8}{|c|}{ Seed attributes* } \\
\hline Grain yield $\left(\mathrm{Kg} \cdot \mathrm{ha}^{-1}\right)$ & 2.200 & & 143.1 & 6.5 & & & & \\
\hline MTS (g) & 116.60 & 28.81 & 5.37 & 4.60 & 106.70 & 129.00 & 0.58 & -0.20 \\
\hline $\mathrm{G}(\%)$ & 87.67 & 40.35 & 6.35 & 7.25 & 73.00 & 98.00 & -0.40 & -0.62 \\
\hline FCG $(\%)$ & 74.97 & 74.91 & 8.66 & 11.54 & 52.00 & 91.00 & -0.57 & 0.34 \\
\hline AA $(\%)$ & 69.12 & 113.40 & 10.65 & 15.40 & 45.00 & 92.00 & -0.31 & 0.21 \\
\hline
\end{tabular}

*MTS - Mass of 1,000 Seeds; G - Germination; FCG - First Count of Germination; AA - Accelerated Aging.

Through the CV classification proposed by Wilding e Drees (1983), it was observed that $\mathrm{pH}, \mathrm{Ca}$, and $\mathrm{V} \%$ had low variability, i.e., $\mathrm{CV}<15 \%$; Mn presented high variability $(\mathrm{CV}=82.42 \%)$; and the remaining attributes were sorted as of moderate variability $(15 \%<\mathrm{CV}<35 \%)$. In contradiction to what has been observed within this study, some authors have reported that the $\mathrm{K}$ content available for the plants presents high values for $\mathrm{CV}$, while the values for the $\mathrm{P}$ available are normally high, remaining in the range of $40 \%$ to $80 \%$ (Johnson et al., 2002; Silva et al., 2007; Ward and Cox, 2000). Grain yield and physiological potential of seeds presented low $\mathrm{CV}$, what is in accordance with what was observed by other authors, who obtained
CV values varying from $8 \%$ to $29 \%$ (Pierce et al., 1995; Ping e Green, 2000). Although CV values from low to moderate have occurred, these parameters per se, are not suitable indicators of spatial variability for soil attributes, once some spots can occurs in the field with extremely high or low values (Wollenhaupt et al., 1997).

The Pearson's linear correlation analysis has shown that low correlations between soil chemical attributes and physiological potential of seeds actually occurred (Table 2). In its turn, soil organic matter content was positively correlated with seed germination. This fact is probably related with the higher water retention and its availability for the crops promoted by organic matter, since hydric deficit 
affects metabolism and impairs plant growth. There are also reductions on leaf area and on photosynthetic rate, which lead to a lower supply of photosynthates, flower abortion and/or reduction on the development of seeds (Marcos-Filho, 2005).

Table 2. Pearson's linear correlation between soil attributes and factors that determine physiological quality of seeds: grain yield (GY); mass of 1,000 seeds (MTS); germination (G); first count of germination (FCG); and accelerated aging (AA). Assessments performed in soybean seeds.

\begin{tabular}{cccccc}
\hline \multirow{2}{*}{ Attributes } & \multicolumn{5}{c}{ Seeds attributes } \\
\cline { 2 - 5 } & GY & MTS & G & FCG & AA \\
\hline Organic matter & $-0.16^{\mathrm{NS}}$ & $0.03^{\mathrm{NS}}$ & $0.54^{* *}$ & $0.16^{\mathrm{NS}}$ & $0.28^{\mathrm{NS}}$ \\
$\mathrm{pH}$ & $0.07^{\mathrm{NS}}$ & $-0.17^{\mathrm{NS}}$ & $-0.10^{\mathrm{NS}}$ & $-0.05^{\mathrm{NS}}$ & $0.05^{\mathrm{NS}}$ \\
$\mathrm{P}$ & $0.32^{\mathrm{NS}}$ & $0.03^{\mathrm{NS}}$ & $0.18^{\mathrm{NS}}$ & $0.27^{\mathrm{NS}}$ & $0.25^{\mathrm{NS}}$ \\
$\mathrm{K}$ & $-0.03^{\mathrm{NS}}$ & $-0.17^{\mathrm{NS}}$ & $0.10^{\mathrm{NS}}$ & $0.05^{\mathrm{NS}}$ & $0.18^{\mathrm{NS}}$ \\
$\mathrm{Ca}$ & $-0.25^{\mathrm{NS}}$ & $-0.21^{\mathrm{NS}}$ & $0.28^{\mathrm{NS}}$ & $0.06^{\mathrm{NS}}$ & $0.18^{\mathrm{NS}}$ \\
$\mathrm{Mg}$ & $-0.22^{\mathrm{NS}}$ & $-0.34^{\mathrm{NS}}$ & $0.10^{\mathrm{NS}}$ & $-0.03^{\mathrm{NS}}$ & $0.04^{\mathrm{NS}}$ \\
$\mathrm{V} \%$ & $0.22^{\mathrm{NS}}$ & $-0.16^{\mathrm{NS}}$ & $-0.12^{\mathrm{NS}}$ & $-0.10^{\mathrm{NS}}$ & $0.11^{\mathrm{NS}}$ \\
$\mathrm{B}$ & $-0.43^{*}$ & $0.15^{\mathrm{NS}}$ & $0.22^{\mathrm{NS}}$ & $0.23^{\mathrm{NS}}$ & $0.18^{\mathrm{NS}}$ \\
$\mathrm{Fe}$ & $-0.41^{*}$ & $0.11^{\mathrm{NS}}$ & $0.33^{\mathrm{NS}}$ & $0.09^{\mathrm{NS}}$ & $0.20^{\mathrm{NS}}$ \\
$\mathrm{Mn}$ & $0.52^{* *}$ & $-0.08^{\mathrm{NS}}$ & $-0.55^{* *}$ & $-0.27^{\mathrm{NS}}$ & $-0.32^{\mathrm{NS}}$ \\
$\mathrm{Cu}$ & $0.03^{\mathrm{NS}}$ & $-0.45^{* *}$ & $-0.37^{*}$ & $0.18^{\mathrm{NS}}$ & $0.09^{\mathrm{NS}}$ \\
$\mathrm{Zn}$ & $-0.04^{\mathrm{NS}}$ & $-0.21^{\mathrm{NS}}$ & $-0.31^{\mathrm{NS}}$ & $0.33^{\mathrm{NS}}$ & $0.00^{\mathrm{NS}}$ \\
$\mathrm{GY}$ & 1 & $0.33^{\mathrm{NS}}$ & $-0.09^{\mathrm{NS}}$ & $0.18^{\mathrm{NS}}$ & $-0.07^{\mathrm{NS}}$ \\
$\mathrm{MTS}$ & - & 1 & $0.23^{\mathrm{NS}}$ & $-0.28^{\mathrm{NS}}$ & $0.21^{\mathrm{NS}}$ \\
$\mathrm{G}$ & - & - & - & $0.74^{* *}$ & $0.78^{* *}$ \\
FCG & - & - & - & 1 & $0.62^{* *}$ \\
$\mathrm{AA}$ & - & - & - & - & 1 \\
\hline
\end{tabular}

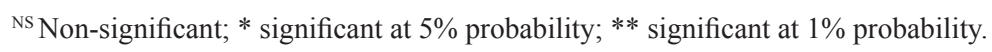

$\mathrm{Mn}$ is related to lignin formation that, in its turn, is one of the substances present in the cellular wall, conferring impermeability to it (McDougall et al., 1996), this way exerting significant effect on capacity and speed of water absorption through the tegument. Panobianco et al. (1999) found higher values of electric conductivity in soybean seeds with low lignin content in the tegument due to the higher amount of substances lixiviate to the water in which the seeds had been immersed. This information can explain the occurrence of significant correlation between content of that element and physiological potential of seeds.

As related to micronutrients, it was observed that grain yield was positively affected by Mn contents while germination had an opposite behavior, i.e., the correlation was negative. Mann et al. (2002) observed that $\mathrm{Mn}$ application on soybean crop increased grain yield and seed germination. Melarato et al. (2002), however, observed that application of Mn had positive influence on seed mass and on nutritional conditions of soybean plants without influencing physiological potential of seeds produced.

The geostatistics analysis (Table 3 ) revealed that content of B in the soil, mass of 1,000 seeds, and first count of germination did not present dependence (Nugget Effect) within the sampling range used in this study. Data for the variables: $\mathrm{P}, \mathrm{Ca}, \mathrm{Mg}, \mathrm{Mn}, \mathrm{Cu}$, and $\mathrm{Zn}$ in the soil, germination and accelerated aging of seeds, suitably fitted the spherical semivariogram; and the variables $\mathrm{Mo}, \mathrm{pH}$ and $\mathrm{K}$ better fitted the Gaussian model. Data for the variables $\mathrm{V} \%$ and $\mathrm{Fe}$ fitted the linear model, i.e., the sill of semivariance was not reached within the area studied and would continue to increase if the area was larger.

In this study it was observed that for variables $\mathrm{P}, \mathrm{K}$, $\mathrm{V} \%, \mathrm{Cu}$, and $\mathrm{Zn}$ as well as mass of 1,000 seeds (MTS) 
presented DSD from moderate to high for $\mathrm{Mo}, \mathrm{pH}, \mathrm{Ca}$, $\mathrm{Mg}$, and $\mathrm{Mn}$ in the soil and for AA of seeds. According to Cambardella et al. (1994), attributes that present strong dependence are more influenced by intrinsic properties of soil such as texture and mineralogy; while those with weaker dependence are more influenced by external factors such as fertilizers application and soil preparation and cultivation, i.e., by soil management.

In the analysis of semivariograms, it was observed a large amplitude in range values of variables analyzed, which varied from $89.9 \mathrm{~m}$ for P until $651.4 \mathrm{~m}$ for Fe. The range value is also an important tool in defining sampling schemes; in this case the samplings have to be performed within the lowest range value.

Table 3. Parameters of semivariograms adjusted to data for soil attributes and physiological potential of soybean seeds.

\begin{tabular}{|c|c|c|c|c|c|c|c|}
\hline Variable & Model & $\mathrm{C}_{0}$ & $\mathrm{C}_{1}$ & Range (m) & $\mathrm{R}^{2}$ & SRME & DSD \\
\hline \multicolumn{8}{|c|}{ Soil attributes } \\
\hline $\mathrm{P}$ & Spherical & 29.10 & 39.79 & 89.9 & 0.015 & 12.58 & 0.58 \\
\hline Organic matter & Gaussian & 4.69 & 30.50 & 498.2 & 0.964 & 3.59 & 0.87 \\
\hline $\mathrm{pH}$ & Gaussian & 0.017 & 0.045 & 650.0 & 0.967 & 0.01 & 0.72 \\
\hline K & Gaussian & 0.047 & 0.018 & 422.7 & 0.803 & 0.03 & 0.27 \\
\hline $\mathrm{Ca}$ & Spherical & 0.90 & 12.46 & 339.6 & 0.622 & 1.86 & 0.93 \\
\hline $\mathrm{Mg}$ & Spherical & 0.43 & 1.40 & 403.0 & 0.709 & 0.20 & 0.77 \\
\hline $\mathrm{V}(\%)$ & Linear & 10.14 & 29.03 & 651.0 & 0.735 & 4.67 & 0.74 \\
\hline B & Nugget effect & & & & & & \\
\hline $\mathrm{Fe}$ & Linear & 0 & 34.25 & 651.4 & 0.800 & 2.73 & 1.00 \\
\hline $\mathrm{Mn}$ & Spherical & 0 & 50.62 & 582.7 & 0.757 & 4.49 & 1.00 \\
\hline $\mathrm{Cu}$ & Spherical & 0.00 & 0.01 & 100.0 & 0.962 & 0.00 & 0.63 \\
\hline $\mathrm{Zn}$ & Spherical & 0.19 & 0.14 & 260.2 & 0.323 & 0.05 & 0.42 \\
\hline \multicolumn{8}{|c|}{ Seed attributes } \\
\hline MTS & Nugget effect & & & & & & \\
\hline $\mathrm{G}$ & Spherical & 18.88 & 24.76 & 375.5 & 0.955 & 6.27 & 0.57 \\
\hline FCG & Nugget effect & & & & & & \\
\hline $\mathrm{AA}$ & Spherical & 3.50 & 103.40 & 96.8 & 0.174 & 14.06 & 0.97 \\
\hline
\end{tabular}

MTS - Mass of 1,000 Seeds; G - Germination; FCG - First Count of Germination; AA - Accelerated Aging; $C_{0}$ : Nugget effect; $C_{1}$ : Structural variance; $\mathrm{R}^{2}$ : Coefficient of determination; SRME: Square Root of Mean Error; DSD: Degree of Spatial Dependence.

When spatial dependence occurred, the parameters of semivariogram were used for drawing spatial distribution maps for variables. Through these maps it was possible to verify the spatial distribution of nutrient contents and quality of seeds. By analyzing the variable 'grain yield', which had large variability of results and was dispersed within all the area, it was not possible to clearly identify the defined zones of grain yield (Figure 2a). When the values of seed germination were analyzed, in practically the whole area the values for percentage of germination were situated above the standards values for minimum germination required for commercialization of soybean seeds, which is set at
80 (Embrapa, 2006) (Figure 2b). Taking such aspects into account, despite variability of nutrients in the soil, and besides the critical content that some elements had assumed in some spots within the area, there has been only a small interference on the physiological potential of seeds, mainly related to germination. Delouche (1980) has stressed that the typical response of plants, cultivated in low fertility soils, is reduction on quantity of seeds produced and not on their quality. Mainly plants subjected to hydric stress, which preferentially regulate the translocation of their photosynthates to the seeds, in an attempt of guaranteeing the species perpetuation. 


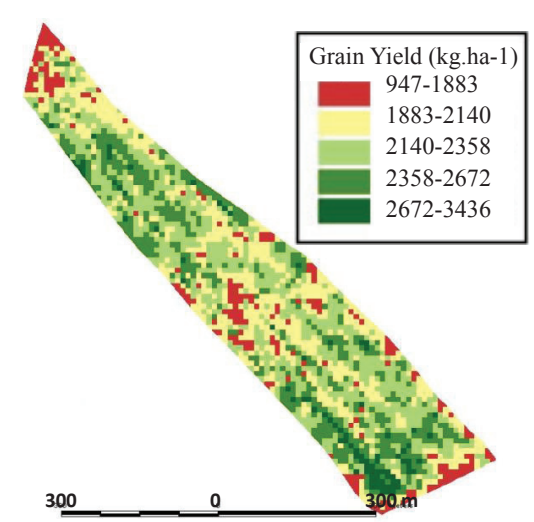

(a)

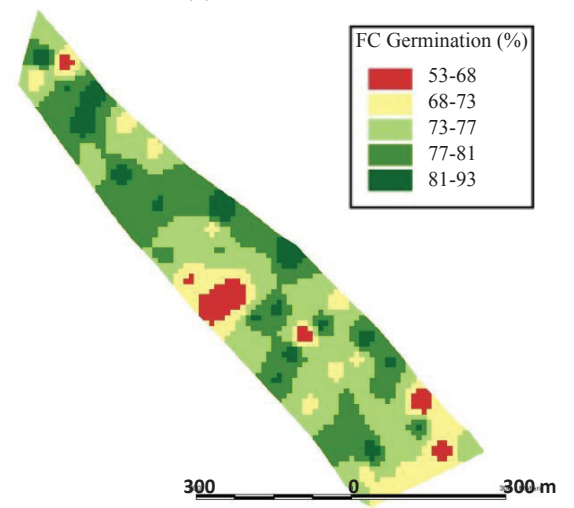

(c)

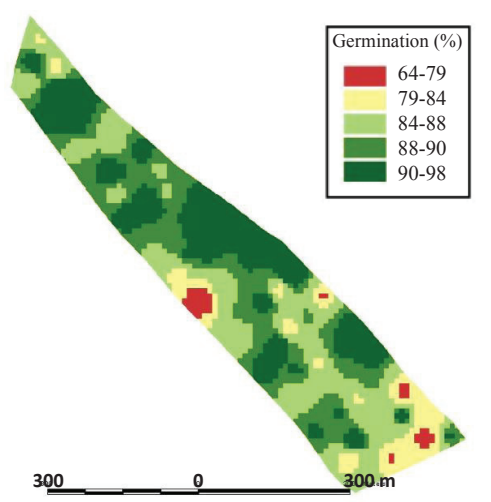

(b)

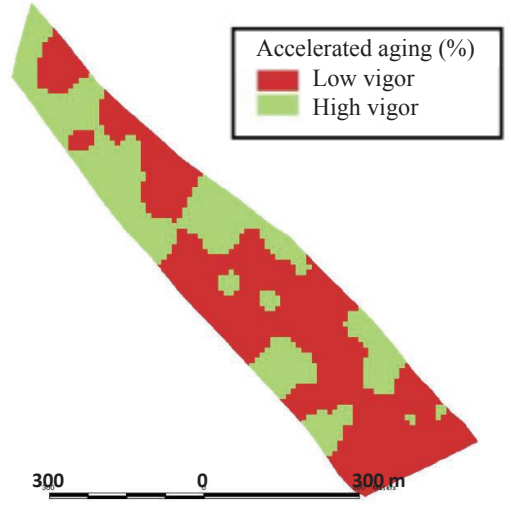

(d)

Figure 2. Spatial distribution maps for: (a) grain yield $\left(\mathrm{Kg}_{\mathrm{g}} \mathrm{ha}^{-1}\right)$; (b) germination; (c) first count of germination; and (d) accelerated aging, for soybean seeds.

\section{Conclusions}

Organic matter content, $\mathrm{Mn}$ and $\mathrm{Cu}$ in the soil have significant effects on soybean seeds germination;

Spatial dependences among studied variables exist and are, in majority, high and moderate;

The range values for spatial dependences varied from $89.9 \mathrm{~m}$ for P until $651.4 \mathrm{~m}$ for $\mathrm{Fe}$, and these values have to be considered in defining soil sampling schemes for assessment of fertility.

\section{Referências}

BRASIL. Ministério da Agricultura, Pecuária e Abastecimento. Regras para análise de sementes. Ministério da Agricultura, Pecuária e Abastecimento. Secretaria de Defesa Agropecuária. Brasília: MAPA/ACS, 2009. 395p. http://www.agricultura.gov.br/arq_editor/file/Laborat $\%$ C3\%B3rio/ Sementes/Regras\%20para\%20Analise\%20de\%20Sementes.pdf

CAMBARDELLA. C.A.; MOORMAN, T.B.; NOWAK, J.M.; PARKIN, T.B.; KARLEN, D.L.; TURCO, R.F.; KONOPKA, A.E. Field-scale variability of soil properties in central Iowa soils. Soil Science Society of
America Journal, v.58, p.1501-1511, 1994. http://phoenix.nal.usda.gov/ bitstream/10113/18168/1/ind20518015.pdf

CARVALHO, N.M.; NAKAGAWA, J. Sementes: ciência, tecnologia e produção. Jaboticabal: FUNEP, 2000. 588p.

CORÁ, J.E.; ARAUJO, A.V.; PEREIRA, G.T.; BERALDO, J.M.G. Assessment of spatial variability of soil atributes as a basis for adoption of precision agriculture in sugarcane plantations. Revista Brasileira de Ciência do Solo, v.28, p.1013-1021, 2004. http://www.scielo.br/pdf/rbcs/v28n6/22923.pdf

CRUSCIOL, C.A.C.; LIMA, E.D.; ANDREOTTI, M.; NAKAGAWA, J.; LEMOS, L.B; MARUBAYASHI, O.M. Nitrogen effect on the productivity, physiological quality and characteristics of dry bean seed. Revista Brasileira de Sementes, v.25, n.1, p.108-115, 2003. http://www. scielo.br/pdf/\%0D/rbs/v25n1/19638.pdf

DELOUCHE, J.C. Environmental effects on seed development and seed quality. HortScience, v.15, p.775-780, 1980.

EMBRAPA. Empresa Brasileira de Pesquisa Agropecuária. Tecnologias de produção de soja - região central do Brasil - 2007. Londrina: Embrapa Soja: Embrapa Cerrados: Embrapa Agropecuária Oeste, 2006. 225p.

FARINELLI, R.; LEMOS, L.B.; CAVARIANI, C.; NAKAGAWA, J. 
Productivity and physiological quality of common bean seeds in function of soil tillage systems and nitrogen fertilization. Revista Brasileira de Sementes, v.28, n.2, p.102-109, 2006. http://www.scielo.br/pdf/rbs/ v28n2/a13v28n2.pdf

JOHNSON, R.M.; DOWNER, R.G.; BRADOW, J.M.; BAUER, P.J.; SADLER, E.J. Variability in cotton fiber yield, fiber quality and soil properties in a Southeastern Coastal Plain. Agronomy Journal, v.94, p.1305-1316, 2002. http://agdb.nal.usda.gov/bitstream/10113/11454/1/ IND23320768.pdf

KHAKURAL, B.R.; ROBERT, P.C.; HUGGINS, D.R. Variability of corn/ soybean yield and soil/landscape properties across a southern Minnesota landscape. In INTERNATIONAL CONFERENCE OF PRECISION AGRICULTURE, 4., 1999. Madison. Proceedings... Madison, WI: ASA/ CSSA/SSSA, 1999.. p.573-579.

KRAVCHENKO, A.N.; BULLOCK, D.G. Correlation of corn and soybean grain yield with topography and soil properties. Agronomy Journal, v.92, p.75-83, 2000. https://www.crops.org/publications/aj/ articles/92/1/75

MANN, E.N.; RESENDE, P.M.; MANN, R.S.; CARVALHO, J.G.; VON PINHO, E.V.R. Effect of manganeses application on yield and seed quality of soybean. Pesquisa Agropecuária Brasileira, v.37, n.12, p.1757-1764, 2002. http://www.scielo.br/pdf/pab/v37n12/14643.pdf

MARCOS-FILHO, J. Fisiologia de sementes de plantas cultivadas. Piracicaba: FEALQ, 2005. 495p.

MARCOS-FILHO, J. Teste de envelhecimento acelerado. In: KRZYZANOWSKI, F.C; VIEIRA, R.D.; FRANÇA-NETO, J.B. Vigor de sementes: conceitos e testes. Londrina: ABRATES, Comitê de Vigor de Sementes, p.1-24, 1999.

McBRATNEY, A.; WHELAN, B.; ANCEV, T; BOUMA, J. Future Directions of Precision Agriculture. Precision Agriculture, v.6, n.1, p.7-23, 2006. http://www.springerlink.com/content/r4k236p6582x2143/fulltext.pdf

McDOUGALl, G.J.; MORRISON, I.M.; STEWART, D.; HILLMAN, J.R. Plant cell walls as dietary fibre: range, structure, processing and function. Journal Science Food Agriculture, v.70, n.2, p.133150, 1996. http://onlinelibrary.wiley.com/doi/10.1002/(SICI)10970010(199602)70:2\%3C133::AID-JSFA495\%3E3.0.CO;2-4/pdf

MELARATO, M.; PANOBIANCO, M.; VITTI, G.C.; VIEIRA, R.D. Manganese and physiological quality of soybean seeds. Ciência Rural, v.32, n.6, p.1069-1071, 2002. http://www.scielo.br/pdf/\%0D/cr/ v32n6/12757.pdf

ORTEGA, R.A.; ESSER, A.; SANTIBANEZ, O. Spatial variability of wine grape yield and quality in Chilean vineyards: economic and environmental impacts. In: EUROPEAN CONFERENCE ON PRECISION AGRICULTURE, 4., 2003, Berlin. Proceedings ... Wageningen: Wageningen Academic Publ., 2003. p.499-506.

PANOBIANCO, M.; VIEIRA, R.D.; KRZYZANOWSKI, F.C.; FRANÇA-
NETO, J.B. Electrical conductivity of soybean seed and correlation with seed coat lignin content. Seed Science and Technology, v.27, n.3, p.945949, 1999. http://cat.inist.fr/?aModele $=$ afficheN\&cpsidt=1283845

PIERCE, F.J.; WARNCKE, D.D.; EVERETT, M.W. Yield and nutrient variability in glacial soils of Michigan. In: ROBERT, P.C.; RUST, R.H.; LARSON, W.E. (Ed.). The site-specific management for agricultural systems. Madison: ASA; CSSA; SSSA, 1995. p.133-151.

PING, J.; GREEN, C.J. Spatial variability of yield and soil parameters in two irrigated cotton fields in Texas. In: INTERNATIONAL CONFERENCE ON PRECISION AGRICULTURE, 5., 2000, Minneapolis. Proceedings ... Madison: ASA; CSSA; SSSA. 2000. p.1-13. 1CD-ROM.

PLANT, R.E.; MERMER, A.; PETTYGROVE, G.S.; VAYSSIERES, M.P.; YOUNG, J.A.; MILLER, R.O.; JACKSON, L.F.; DENISON, R.F.; PHELPS, K. Factors underlying grains yield spatial variability in three irrigated wheat fields. Transactions of the ASAE, v.42, n.5, p.1187-1202, 1999. http://cat.inist.fr/?aModele $=$ afficheN\&cpsidt=1355171

RAIJ, B. ; SILVA, N.M.; BATAGLIA, O.C.; QUAGGIO, J.A.; HIROCE, L.; CANTARELLA, H.; BELLINAZZI JÚNIOR, R.; DECHEN, A.R.; TRANI, P.E. Recomendações de adubação e calagem para o Estado de São Paulo. Campinas: IAC, Boletim Técnico 100, 1996. 107p.

RUNGE, E.C.A.; HONS, F.M. Precision agriculture - development of a hierarchy of variables influencing crop yields. In: INTERNATIONAL CONFERENCE ON PRECISION AGRICULTURE, 4. 1998, St Paul. Proceedings...St Paul, ASA; CSSA; SSSA, 1998, p.143-158. 1CD-ROM.

SILVA, F.M.; SOUZA, Z.M; FIGUEIREDO, C.A.P.; MARQUES JÚNIOR, J.; MACHADO, R.V. Spatial variability of chemical atributes and productivity in the coffee cultivation. Ciência Rural, v.37, p.401407, 2007. http://www.scielo.br/pdf/cr/v37n2/a16v37n2.pdf

STOORVOGEL, J.J.; BOUMA, J.; OHRLICH, R.A. Participatory research for systems analysis: prototyping for a Costa Rican Banana Plantation. Agronomy Journal, v.96, p.323-336, 2004. https://www.soils. org/publications/aj/pdfs/96/2/323

STOORVOGEL, J.J.; ORLICH, R.A.; VARGAS, R.; BOUMA, J. Linking information technology and farmer knowledge in a decision support system for improved banana cultivation. In: BOUMAN, B.A.M.; JANSEN, H.G.P.; SCHIPPER, R.A.; HENGSDIJK, H.; NIEUWENHUYSE, A. (Eds.). Tools for land use analysis on different scales. Kluwer Academic Publishers, Dordrecht, the Netherlands. p.199-212, 2000.

TISSEYRE, B.; MAZZONI, C.; ARDOIN, N.; CLIPET, C. Yield and harvest quality measurement in precision viticulture - application for a selective vintage. In: EUROPEAN CONFERENCE ON PRECISION AGRICULTURE, 3., 2001, Montpellier. Proceedings ... Montpellier: Agro Montpellier, 2001. p. 133-138, 2001. CD ROM.

VIEIRA, S.R. Geoestatística em estudos de variabilidade espacial do solo. In: NOVAIS, R.F.; ALVARES, V.H.; SCHAEFFER, C.E.G.R. Tópicos em ciência do solo. Viçosa: Sociedade Brasileira de Ciência do Solo, 2000. p.1-54. 
VIEIRA, S.R.; MILLETE, J.A.; TOPP, G.C.; REYNOLDS, W.D. Handbook for Geostatistical analysis of variability in soil and meteorological paramaters. In: Tópicos em Ciência do Solo. v.2. ALVAREZ, V.H (Ed.). Viçosa: Sociedade Brasileira de Ciência do Solo, p.1-45, 2002.

WARD, B.D.; COX, M.S. Influences of soil chemical and physical properties on site-specific cotton production. In: INTERNATIONAL CONFERENCE ON PRECISION AGRICULTURE, 5., 2000, Minneapolis. Proceedings ... Madison: ASA; CSSA; SSSA. 2000. 1 CD-ROM.
WILDING, L.P.; DREES, L.R. Spatial variability and pedology. In: WILDING, L.P.; DREES, L.R., (Eds). Pedogenesis and soil taxonomy: concepts and interactions. New York: Elsevier, 1983. p.83-116.

WOLlENhaUPT, N.C.; MULlA, D.J.; CRAWFORD, C.A.G. Soil Sampling and interpolation techniques for mapping spatial variability of soil properties. In: PIERCE, J.P.; SADLER, E.J. (Eds.). The site-specific management for agricultural systems. Madison, ASA-CSSA- SSSA, 1997. p.19-53. 